\title{
The Effect Of Disclosure Patterns Of Risk Factors In Prospectus On The Relation Between Strategic Alliances And Underpricing Of Biotechnology IPOs
}

Ying Guo, California State University, East Bay, USA

Tawei Wang, DePaul University, USA

Jia-Lang Seng, National Chengchi University, Taiwan

San-Shuan Hung, PricewaterhouseCoopers (PwC), Taiwan

\begin{abstract}
This study observes a significantly negative moderating effect of the disclosing patterns of risk factors in initial public offerings (IPOs) prospectus on the association between strategic alliances and underpricing of biotechnology IPOs. Our findings suggest that strategic alliances mitigate information uncertainties when risk factor disclosures are less helpful, which alleviates the underpricing.
\end{abstract}

Keywords: Risk Factors; Strategic Alliance; IPO Underpricing

\section{INTRODUCTION}

C $\mathrm{n}$ the past several years, the market for new biotechnology IPOs has been very strong. For instance, $76 \%$ of the biotechnology IPOs in 2014 collects more than 50 million USD. The strong trend of IPOs in recent years has raised concerns of a "BioBubble." Underpricing of initial public offerings (IPOs) is a prevalent worldwide phenomenon. The most prominent explanation is asymmetric information (Rock, 1986), which suggests that underpricing is directly related to the uncertainty of a firm. The information regarding the IPO firm's uncertainty can be obtained through risk factors disclosed in the IPO prospectus, which is negatively associated with initial underpricing (e.g., Hanley and Hoberg, 2010; Ding, 2016).

Biotechnology firms' operations are inherently more complex. They are normally growing fast with novel products development undergoing, and their firm values are difficult to measure, the further understanding of the association between information uncertainty and initial underpricing becomes especially critical and challenging. Moreover, different from firms in other industries, biotechnology firms rely heavily on strategic alliances. Strategic alliances often play key roles in biotechnology firm's operations, such as providing financial capital, sharing expertise, and helping the product development processes (Guo et al., 2004), and signal a firm's quality, which affects the firm's IPO performance (Stuart et al., 1999). It seems that with the presence of strategic alliances, the uncertainty of the IPO firm is reduced. Differently, strategic alliances, argued by Pisano (1991), may also negatively affect biotechnology firms' long term growth potential because strategic alliances could limit the development of innovation capabilities of new biotechnology firms and raise concerns of the loss of intellectual property rights. All these factors can also increase the biotechnology IPO firm's uncertainties.

From the above discussion, it is not ex ante clear how the disclosure of risk factors interacts with the existence of strategic alliance in affecting uncertainties for biotechnology IPOs. Accordingly, in this study, we explore how disclosing patterns of risk factors in IPO prospectus would affect the association between strategic alliances and IPO underpricing. Our findings suggest that the vague disclosing patterns of risk factors dampen the negative association between the existence of strategic alliances and IPO underpricing. 
We believe this stream of research requires more attention from academic researchers to help (1) investors understand how the information environment in the pre-IPO stage interacts with the disclosed risk factors and how the interaction may be included in the pricing processes, (2) investors understand the role played by third parties in the IPO pricing processes for biotechnology firms, and (3) regulators to potentially mandate the disclosure of preIPO alliances as part of the moderating effect of the disclosed risk factors.

The rest of this paper is organized in the following manner: Section 2 provides literature review and hypothesis development; Section 3 introduces the research methodology; Section 4 provides the data source, sample, and data analysis; and the last section is the conclusion.

\section{THOERY AND HYPOTHESE DEVELOPMENT}

Typically, it takes more than ten years for a biotech firm to complete its product value chain: starting from founding, through R\&D expending, then patenting, then getting FDA approval and finally selling the new product. Because of this feature, the biotech firm has large capital needs over a long period of time. Such capital needs can be satisfied through IPO or mergers and acquisitions by large pharmaceutical companies. Therefore, the IPO underpricing and strategic alliances are two interesting issues to investigate for biotech firms. In the following parts, we review IPO underpricing literatures first and then strategic alliance. Mainly based on asymmetric information and signaling theory, we will develop our hypothesis.

\subsection{IPO Underpricing and Risk Disclosure}

Underpricing of IPO phenomenon has been discussed in literatures since the early of 1970's (Reilly and Hatfield, 1969; Stoll and Curley, 1970; McDonald and Fisher, 1972; Logue, 1973; Reilly, 1973; Ibbotson, 1975). Among the various explanations of IPO underpricing, asymmetric information theory is widely recognized (Baron, 1982; Rock, 1986; et al.). Specifically, Baron (1982) proposes that the asymmetric information between firms and investment bankers is the cause of IPO underpricing: the issued firms lower initial offering price to exchange investment bankers' superior information about the capital market. Differently, Rock (1986) considers the information asymmetry among different groups of investors. Rock (1986) theorizes "winner's curse" and views that IPO underpricing is an outcome of rational behavior of issuers when information asymmetry among different parties exists (Givoly and Shi 2008). More specifically, there are "informed investors" (e.g. investment institution) and "uninformed investors" in the stock market. Informed investors have superior information during the valuation of the issuer. Benefit from such information, the informed investors won't take overpriced IPOs but only the underpriced IPOs. However, the uninformed investors could still subscribe the overpriced IPOs due to information asymmetry. In the long run, uninformed investors have greater probability of making overpricing investment. They will gradually loss the incentives of investment and withdraw from the stock market. Therefore, in order to motivate the uninformed investors to participate in the IPO market, issuers often underprice the securities to compensate the uninformed investors for the risk of investing overprice offering.

Rock's model has been validated by a number of empirical studies. Beatty and Ritter (1986) quote Rock's theory and introduce ex-ante uncertainty ${ }^{1}$ to measure the degree of asymmetric information. Using the number of use of proceeds listed in the prospectus as a proxy for ex-ante uncertainty, Beatty and Ritter (1986) observe a positive relation between the ex-ante uncertainty of an IPO issuer and its expected initial stock return. Beatty and Ritter (1986) suggest that as ex-ante uncertainty increases, uninformed investors tend to become informed through conducting more thoroughly security analysis. By taking extra efforts, they learn to differentiate the undesirable offering from those are likely to appreciate in price. Because becoming informed investors from uninformed ones incurs additional cost, the potential investors expect compensation for such additional costs from issuers. As a response, in order to attract the subscription of uninformed investors for shares in an offering with greater ex-ante uncertainty, issuers choose to underprice.

\footnotetext{
1 "ex-ante uncertainty" means the degree of uncertainty about the value of the IPOs for investors in primary market. Even though on average initial public offerings are underpriced, an investor submitting a purchase order cannot be certain about an offering's value once it starts publicly trading (Beatty and Ritter 1986).
}

Copyright by author(s); $\underline{\text { CC-BY }}$ 
Beatty and Ritter (1986) also adopt the inverse of the gross proceeds to be a proxy for ex-ante uncertainty because the smaller offerings are more speculative, generally speaking, than the larger offerings since the larger offerings are usually issued by well-established firms with less information asymmetry. Therefore, offering size can signal the public about the relative quality and stability of an offering (Ibbotson and Ritter 1995). The empirical analysis indicates that the smaller offerings, ceteris paribus, have substantially the higher average initial returns (Beatty and Ritter 1986). Leone et al. (2007) adopt Rock (1986)'s theory and suggest that IPO issuers with an increase in the extent of dollar detail regarding their intended use of proceeds have less ex-ante uncertainty and experience the lower IPO underpricing. Following Leone et al. (2007)'s measurement of information disclosure, Nam et al. (2008) find that the detailed disclosing information can reduce the uncertainty of the firm and make investors be able to forecast the value of the issuer more accurately. As a result, a negative relation between the information disclosure and underpricing is discovered.

The relation between ex-ante uncertainty and IPO underpricing is consistent when other proxies for ex-ante uncertainty are used. For example, Megginson and Weiss (1991) use firm age, one type of characteristics of company, as a measure of the degree of information asymmetry. In general, more public information is available for the older firms; such information reduces the information asymmetries. Therefore, the older firms have a lower degree of information asymmetry than have younger firms. Megginson and Weiss (1991) observe a significantly negative relationship between the age of the firm and initial returns.

In addition to the use of proceeds or firm age, a number of studies in the prior literature employ the risk factors in the prospectus as a measure of ex-ante uncertainty when testing IPO underpricing.

Note that, Securities Act of 1933 imposes the legal liabilities on the misstatement of IPO issuers to protect public interests. As IPO firms increase the potentially adverse disclosures through the risk factors, they decrease their litigation risks. However, from the perspective of investors, such liability reduction is on the cost of investors since it lowers the successful chance of class-action lawsuit against IPO firms for the misrepresentation. As a result, firms disclosing more risk factors might need to compensate investors for investment risk by increasing IPO underpricing (Beatty and Welch, 1996).

Moreover, the top management of a reporting firm is personal liable to unfaithful presentation of registration statement according to Securities Act of 1933(Feltham et al., 1991). Hence, top management tends to clearly list and discuss risk factors in the registration statement to mitigate the litigation risk. Beatty and Zajac (1994) count the number of risk factors disclosed in the IPO registration statement as a measure of risk and have shown that this measure is an effective way to code risk. Even all risk factors are not equally impactful and informative, the more risk factors reported generally show the higher risk level (Certo et al., 2001).

Instead using the total number of risk factors, Welbourne and Andrews (1996) code specific risk factors and come to a summated risk proxy. The presence of the 14 common risk factors is counted in the measure, including technological obsolescence, new product, few or limited products, low number of years in operation, inexperienced management, technical risk, seasonality, customer dependence, supplier dependence, inexperienced underwriters, competition, legal proceedings against company, liability, and government regulation. Arthurs et al. (2008) use Welbourne and Andrews (1996)'s summated risk factors and present a positive relation between risk factors and underpricing.

Similar with Beatty and Zajac(1994) and Welboume and Andrews(1996), etc., Cyr, et al. (2000) construct a summated measure of common types of risk factors in their study on human resource and venture capitals of IPO firms. Some risk factors that they included are dependence on key employees, competitive labor markets, and so on. Certo et al. (2001) consider other sets of risk factors listed in the firms' prospectuses, including manufacturing capacity limitations, rapid technological change, intense competition, need for additional capital, and uncertainty regarding patents and protection of proprietary rights. 


\subsection{The Impact of Strategic Alliance on the Relation Between IPO Underpricing and Risk Disclosure}

It is difficult to value the IPOs solely based on firm information and its prospects publicly available at the IPO date. Particularly, in biotech IPOs the significant parts of assets are intangibles which are extremely challenge to measure. In addition, there is no historical financial data available for the firms going public. In order to help investors examine the value of biotech IPOs, the biotech firms often disclose the number of alliance agreements to the public (Guo et al., 2005).

Alliance agreements are value-relevant since they generally disclose the contribution of research capabilities or capital by partners. Meanwhile, the alliance agreements themselves alone also deliver a positive signal about the future market potential of the product under development. Guo et al. (2005) observe a positive and significant coefficient between IPO price and alliances. Prior to Guo et al. (2005), numerous studies have investigated the benefits of alliances toward the company's valuation (Pisano, 1991; Gulati, 1999; Stuart et al., 1999; Gulati and Higgins, 2003; Jensen, 2004). Among those, Pisano (1991) indicates that IPO firms in biotechnology tend to tie to major pharmaceutical and health care companies, since those prestige pharmaceutical and health care companies can provide financial, marketing and sales supports which are critical for a new biotech firm. Gulati (1999) emphasizes the various opportunities provided through the strategic alliances. For instance, the biotech firms could co-develop the products, share the financial or human capital, technology and skills, or some firm-specific assets with their alliances.

From the signaling effect aspect, Stuart et al. (1999) indicate that the alliance activities of young biotech firms actually deliver extra information about a firm's quality to key stockholders. Jensen (2004) also treats a firm's alliance activity as a valuable market signal since the alliances are widely observable and indicate that a firm's resources and capabilities are in other companies' financial interests. Such signaling effect will affect IPO underpricing. More specifically, Gulati and Higgins (2003) claims that the signal effect of a firm's strategic alliances could vary, for instant, in the hot or cold market situations. They suggest, during cold markets (un-favorite markets) when the funding resource is scarce, the strategic alliance activities may send a prominent positive signal to investors about the future profitability of the new biotechnology firm. Consent with this rational, we believe, the signal implied by strategic alliance is less useful when the disclosures provide clear information. Differently, when the disclosures are less specific and unclear, the role played by strategic alliance on underpricing becomes more prominent. That is, when investors cannot obtain sufficient information from the IPO prospectus, they turn to seek other elements in the information environment that can be used to infer the uncertainty of the IPO, which in our case is the existence of strategic alliance. Therefore, we propose our hypotheses as following:

H1: The strategic alliances are significantly negatively associated with IPO underpricing.

H2: When the risk disclosing pattern is less specific and inexplicit, the abovementioned association becomes more prominent.

\section{METHODOLOGY}

\subsection{Research Model}

We use Equation (1) to investigate our research question. Equation (1) is estimated by using the ordinary least squares (OLS) model with industry and year fixed effect and company-clustered standard errors. Equation (1) is also estimated without the consideration of disclosed risk factors, with low level of disclosed risk factors and with high level of disclosed risk factors.

$$
\begin{aligned}
& \text { Underpricing }(I R)=\beta_{0}+\beta_{1} D A L L I A N C E+\beta_{2} A G E+\beta_{3} S I Z E+\beta_{4} D V C+\beta_{5} A D J P+ \\
& \beta_{6} P R E_{-} R E T U R N+\text { Year }+\sum \text { Industry }+\varepsilon
\end{aligned}
$$

Underpricing is measured by the initial return $(I R)$, calculated as the closing price of the first day of IPO minus the offer price divided by the offer price (Beatty and Ritter 1986). DALLIANCE is a dummy variable, which equals one when there is an alliance before the IPO date and zero otherwise. We control for the age of the company (AGE), 
which is the natural logarithm of the number of years between the IPO year and the company's founding year stated in the IPO prospectus. Public information is generally more accessible for older firms (Muscarella and Vetsuypens, 1989), which may affect the IPO underpricing. SIZE is the natural logarithm of the original filing amount, which signals the quality and stability of the IPO to the market (Ibbotson and Ritter, 1995). Larger IPOs generally are less risky than smaller IPOs (Beatty and Ritter, 1986; Carter et al. 1998; Megginson and Weiss, 1991; Hanley and Hoberg, 2010).

We also control for the existence of venture capital. Venture capital (VC) reduces IPO underpricing due to the certification and monitoring function (e.g., Barry et al. 1990; Megginson and Weiss, 1991; Ljungqvist and Wilhelm, 2003). DVC equals one when the IPO company is VC backed and zero otherwise. The "partial adjustment" effect $(A D J P)$, which is the difference between the final offer price and the midpoint of the initial offer price range, divided by the midpoint of the initial offer price range, is considered. The adjusted offer price only partially adjusts to the private information shared by investors, which positively affects underpricing (Ibbotson et al., 1988; Hanley, 1993). Last, we control for the pre-filing returns (PRE_RETURN) because in a hot market, investors' activities increase and the anticipation on premium also increases, which results in larger underpricing (Ritter, 1984). PRE_RETURN is calculated as the return of the CRSP equal-weighted portfolio of NYSE-, AMEX-, and NASDAQlisted stocks for the thirty trading days preceding the filing date (Loughran and Ritter, 2004; Hanley and Hoberg, 2010). To capture the industry difference (SIC 2834, 2835, 2836 and 8731), industry dummies are constructed based on SIC code.

In order to capture the disclosure patterns of risk factors revealed in IPO prospectus, we form an index score (SCORE in Table 1) for each company. We first summarize a list of types of risk factors disclosed in IPO prospectus. The risk factors are measured in this study including:

1. Technological obsolescence/ rapid technological change

2. New product

3. Few or limited products

4. Low number of years in operation

5. Inexperienced management

6. Technical risk

7. Seasonality

8. Customer dependence

9. Supplier dependence

10. Inexperienced underwriters

11. Intense competition

12. Legal proceedings against company

13. Liability

14. Government regulation

15. Manufacturing capacity limitations

16. Need for additional capital

17. Uncertainty regarding patents or proprietary rights

18. Termination of contract

19. Dependence on key employees

20. Competitive labor markets

In addition to analyzing the number of items listed in the risk factor section, the second approach to measure risk is in the light of the literature about information disclosure and content analysis. Freedman and Stagliano (1992) suggest that "the meaning of the message is what is important and what is included in the theme, rather than how much is said". Therefore, this study evaluates the content of each item in listed twenty risk factors by weighting score.

For each item on the list, we assign points to each disclosed risk factor items (Cerbioni and Parbonetti 2007; Hughes et al., 2001; Hali 2002). We assign 4 points if the item provides quantitative information or is clearly defined in monetary terms or physical quantities, 3 points if the item provides qualitative information specific to actions, 
persons, events, or places, or the impact on the company is clearly evident, 2 points if the item is vague and general, and 1 point if the information is immaterial to the financial condition or operational results of the company. Two raters perform the coding independently. The inter-rater reliability measured by Cronbach's alpha is larger than 0.9. We sum all the points for each prospectus. The example and score index are provided in Appendix. The total points are defined as SCORE in our analysis and total number of risk items disclosed among the 20 risk items selected as ITEM. For our analysis, we compare the companies with the highest score (the top quintile of SCORE) with the scores of other company to investigate whether the disclosing patterns moderate the association between strategic alliance and IPO underpricing.

\subsection{Data Collection}

We gather all US biotechnology (SIC code 2834-2836, and 8731) IPOs from 1997 to 2012 and the corresponding IPO prospectuses (S-1 filings) from the Securities and Exchange Commission's (SEC's) website. . We start with 231 IPOs observations. After requiring S-1 filings data, the resulting sample consists of 208 IPOs. Based on this sample, we collect stock market related information and company characteristics from the Compustat and CRSP databases. We also search for the information about IPOs and strategic alliance for each of the IPO companies through LexisNexis. The final sample includes 208 observations.

\section{RESULTS}

Table 1 provides descriptive statistics regarding all variables for full sample of 208 biotech IPOs during 1997-2012. All variables are winsorized at the $99 \%$ level in order to reduce the impact of outliers on the empirical analysis. Overall, the sample contains an average initial return $(I R)$ of $12.0 \%$ but with a low median of $2.0 \%$. The first quartile shows $0 \%$ representing that about $75 \%$ of IPO initial returns are larger than zero, indicating the existence of underpricing phenomenon. In our sample, about $27.4 \%$ of the firms have strategic alliances before IPO date. Besides, the mean of total risk factor disclosed in the prospectus (among twenty selected risk factors) is 8 items similar to the median. The mean of total risk disclosure score is approximately 21 . The average change in the offer price from the midpoint of the initial offer price range to the final offer price is $-6.3 \%$. The mean of filing amount of IPO offers is approximately $\$ 70.4$ million. The average firm age is about six years. Additionally, close to $84 \%$ of the IPOs have VC backed. Last, an average return in the thirty days prior to filing is $0.1 \%$. Panel B suggests that top quintile discloser firms have higher risk discloser score and more risk items disclosed comparing with the rest firms. They also experience severer underpricing. Other firm characters among the top discloser and the rest are identical. Panel C provides the Person correlation coefficients among variables in analysis. Expect the correlation between SCORE and ITEM, with 0.821 , no strong correlation has been observed among variables. Considering the construction method of SCORE and ITEM, the strong correlation coefficient between those two are expected. 
Table 1. Descriptive Statistics

Panel A. Full Sample

\begin{tabular}{|c|c|c|c|c|c|c|}
\hline \multirow{2}{*}{ Variables } & \multirow{2}{*}{$\mathbf{N}$} & \multirow{2}{*}{ Mean } & \multirow{2}{*}{ Std.Dev. } & \multicolumn{3}{|c|}{ Quartiles } \\
\hline & & & & Q1 & Q2 & Q3 \\
\hline$I R$ & 208 & 0.120 & 0.262 & 0 & 0.020 & 0.190 \\
\hline DALLIANCE & 208 & 0.274 & 0.447 & 0 & 0 & 1 \\
\hline ITEM & 208 & 8.038 & 1.597 & 7 & 8 & 9 \\
\hline SCORE & 208 & 20.971 & 4.316 & 18 & 20.5 & 24 \\
\hline$A G E$ & 208 & 1.811 & 0.558 & 1.386 & 1.946 & 2.197 \\
\hline SIZE & 208 & 4.254 & 0.540 & 4.080 & 4.458 & 4.479 \\
\hline$D V C$ & 208 & 0.837 & 0.371 & 1 & 1 & 1 \\
\hline$A D J P$ & 208 & -0.063 & 0.146 & -0.143 & -0.019 & 0 \\
\hline PRE-RETURN & 208 & 0.001 & 0.007 & -0.002 & 0.001 & 0.005 \\
\hline
\end{tabular}

Panel B. Sample Divided by Risk Disclosure Pattern

\begin{tabular}{|l|c|c|c|c|c|c}
\multirow{2}{*}{\multicolumn{1}{c}{ Variables }} & \multicolumn{3}{c|}{ Top Quintile Discloser } & \multicolumn{3}{c}{ Other Disclosers } \\
\cline { 2 - 8 }$I R$ & $\mathbf{N}$ & Mean & Median & $\mathbf{N}$ & Mean & Median \\
\hline DALLIANCE & 48 & 0.199 & 0.091 & 160 & 0.096 & 0.017 \\
\hline ITEM & 48 & 0.292 & 0.000 & 160 & 0.269 & 0.000 \\
\hline SCORE & 48 & 10.000 & 10.000 & 160 & 7.450 & 7.000 \\
\hline AGE & 48 & 27.063 & 27.000 & 160 & 19.144 & 19.000 \\
\hline SIZE & 48 & 1.717 & 1.792 & 160 & 1.840 & 1.946 \\
\hline DVC & 48 & 4.181 & 4.458 & 160 & 4.276 & 4.458 \\
\hline ADJP & 48 & 0.833 & 1.000 & 160 & 0.838 & 1.000 \\
\hline PRE-RETURN & 48 & -0.038 & 0.000 & 160 & -0.071 & -0.058 \\
\hline & 48 & -0.001 & -0.001 & 160 & 0.001 & 0.001 \\
\hline
\end{tabular}

Panel C. Variable Correlation Table

Pearson Correlation Coefficients

\begin{tabular}{|l|c|c|c|c|c|c|c|c|c|}
\hline & DALLIANCE & ITEM & SCORE & AGE & SIZE & DVC & \multicolumn{1}{c}{ ADJP } & PRE-RETURN \\
\hline IR & -0.090 & 0.079 & $\mathbf{0 . 1 3 6}$ & -0.099 & 0.025 & -0.104 & $\mathbf{0 . 4 5 9}$ & $\mathbf{0 . 1 7 2}$ \\
\hline DALLIANCE & 1 & 0.080 & 0.034 & $\mathbf{0 . 1 9 7}$ & -0.095 & 0.009 & 0.040 & -0.008 \\
\hline ITEM & & 1 & $\mathbf{0 . 8 2 1}$ & -0.045 & -0.130 & 0.019 & 0.057 & -0.054 \\
\hline SCORE & & & 1 & -0.069 & -0.060 & -0.027 & 0.050 & -0.089 \\
\hline AGE & & & 1 & $\mathbf{0 . 1 7 9}$ & -0.002 & -0.119 & 0.021 \\
\hline SIZE & & & & 1 & $\mathbf{0 . 2 3 3}$ & -0.029 & -0.047 \\
\hline DVC & & & & & 1 & -0.092 & -0.036 \\
\hline ADJP & & & & & & & 1 & & 0.039 \\
\hline
\end{tabular}

Note: The bold numbers means that the correlation coefficients are significant at a p-value of $1 \%$ or beyond.

$I R$ : the closing price of the first day of IPO minus the offer price divided by the offer price; SCORE: total score, the sum of the index score per item presented among the selected twenty different types of risk factors commonly listed in the prospectus; ITEM: total items disclosed among the selected twenty different types of risk factors commonly listed in the prospectus; DALLIANCE: a dummy variable, one when there is an alliance before the IPO date and zero otherwise; $A G E$ : the natural logarithm of the number of years between the IPO year and the company's founding year stated in the IPO prospectus; SIZE: the natural logarithm of the original filing amount; DVC: equals one when the IPO company is $\mathrm{VC}$ backed and zero otherwise. $A D J P$ : the difference between the final offer price and the midpoint of the initial offer price range, divided by the midpoint of the initial offer price range; PRE_RETURN: the return of the CRSP equal-weighted portfolio of NYSE-, AMEX-, and NASDAQlisted stocks for the thirty trading days preceding the filing date.

Empirical regression results are given in Table 2. Depend on the sample set applies, there are three models investigated following Equation 1 in Section 3.1. Model (1) demonstrates that the existence of strategic alliance is negatively associated with underpricing (the coefficient of DALLIANCE is $-0.064, p<0.05$ ). This means that strategic alliances play an important role in reducing ex-ante uncertainty and lead to the lower level of underpricing. Therefore, our Hypothesis 1 has been proved. 
There are a few other observations worthy to be mentioned. The significant and positive relation between $I R$ and $A D J P$ (the coefficient of $A D J P$ is $0.708, p<0.001$ ) is consistent with prior literature indicating that underpricing serves to compensate investors for revealing their information (Benveniste and Spindt 1989). PRE-RETURN is positively associated with $I R$ (the coefficient of PRE-RETURN is 5.780 with $p<0.05$ ). Hence, it suggests that past market returns can predict future underpricing and in the hot market, investors will anticipate more premiums which lead to higher underpricing. However, age of a firm and venture capital backing effect are not significant in our analysis.

However, as predicted in our $\mathrm{H} 2$, the association between strategic alliance and IPO underpricing is believed affected by the patterns of risk factors disclosed in IPO prospectus. Specifically, when the disclosing pattern is specific and explicit, for example, for the top quintile of disclosers, the abovementioned association becomes insignificant, where $\mathrm{t}$ value for DALLIANCE coefficient is only equal to -0.30 . The tests on the impact of disclosing pattern are performed following Model (2) and (3) in Table 2. The finding suggests that the signal implied by strategic alliance is less useful when the disclosures provide clear information. Differently, when the disclosures are less specific and unclear, the role played by strategic alliance on underpricing becomes more prominent as given in Model (3). The coefficient of DALLIANCE is significant and negative at $\mathrm{p}$ value of 0.05 level. That is, when investors cannot obtain sufficient information from the IPO prospectus, they turn to seek other elements in the information environment that can be used to infer the uncertainty of the IPO, which in our case is the existence of strategic alliance.

Table 2. Empirical Results

\begin{tabular}{|c|c|c|c|}
\hline Model & $\begin{array}{c}\text { (1) } \\
\text { Full Sample }\end{array}$ & $\begin{array}{c}\text { (2) } \\
\text { Top Quintile Discloser }\end{array}$ & $\begin{array}{c}\text { (3) } \\
\text { Other Disclosers }\end{array}$ \\
\hline \multirow{2}{*}{ Intercept } & $19.668^{* * *}$ & -27.898 & $19.581^{* * *}$ \\
\hline & $(3.25)$ & $(-1.2)$ & $(2.91)$ \\
\hline \multirow{2}{*}{$D A L L I A N C E$} & $-0.064^{* * *}$ & -0.023 & $-0.075^{* *}$ \\
\hline & $(-2.03)$ & $(-0.3)$ & $(-2.17)$ \\
\hline \multirow{2}{*}{ SIZE } & $0.063 * *$ & 0.010 & $0.059 * *$ \\
\hline & $(2.15)$ & $(0.14)$ & $(2.51)$ \\
\hline \multirow{2}{*}{$A G E$} & -0.020 & $-0.135^{*}$ & 0.012 \\
\hline & $(-0.70)$ & $(-1.75)$ & $(0.41)$ \\
\hline \multirow{2}{*}{$D V C$} & -0.056 & $-0.364^{*}$ & 0.024 \\
\hline & $(-0.94)$ & $(-1.99)$ & $(0.69)$ \\
\hline \multirow{2}{*}{$A D J P$} & $0.708^{* * *}$ & $1.109^{* * *}$ & $0.608^{* * *}$ \\
\hline & $(5.53)$ & $(3.13)$ & $(4.86)$ \\
\hline \multirow{2}{*}{ PRE_RETURN } & $5.780^{* *}$ & 5.521 & $6.868^{* *}$ \\
\hline & $(2.31)$ & $(1.38)$ & $(2.04)$ \\
\hline Year and Industry Effect ${ }^{1}$ & Included & Included & Included \\
\hline Cluster & Firm & Firm & Firm \\
\hline$N$ & 208 & 48 & 160 \\
\hline $\operatorname{adj} . R^{2}$ & 0.271 & 0.373 & 0.268 \\
\hline \multicolumn{4}{|c|}{$\begin{array}{l}t \text { statistics in parentheses and are estimated with company-clustered standard errors } \\
{ }^{*} p<.1,{ }^{* *} p<.05,{ }^{* * *} p<.01 \\
\text { 1. To count the industry difference, industry dummies are constructed based on SIC code (SIC=2834, 2835, } 2836 \text { and } 8731 \text { ). } \\
\text { IR: the closing price of the first day of IPO minus the offer price divided by the offer price; DALLIANCE: a dummy variable, one when there is } \\
\text { an alliance before the IPO date and zero otherwise; } A G E \text { : the natural logarithm of the number of years between the IPO year and the company's } \\
\text { founding year stated in the IPO prospectus; SIZE: the natural logarithm of the original filing amount; DVC: equals one when the IPO company is } \\
\text { VC backed and zero otherwise. ADJP: the difference between the final offer price and the midpoint of the initial offer price range, divided by the } \\
\text { midpoint of the initial offer price range; PRE_RETURN: the return of the CRSP equal-weighted portfolio of NYSE-, AMEX-, and NASDAQ- } \\
\text { listed stocks for the thirty trading days preceding the filing date. }\end{array}$} \\
\hline
\end{tabular}

In the robust tests, we check the validity of our proxy of risk disclosure. Following Beatty and Zajac (1994)'s approach, we count the total risk factors disclosed in a firm's filing to SEC as the measure of risk and uncertainty. The un-tabulate results are consistent with our main results reported in Table 2. In addition, to alleviate the concern that the insignificant results for Top Quintile Discloser is driven by the small sample size of 48 in the column (2) of Table 2, we run the main test on the top two quintiles, the coefficient of DALLIANCE keeps insignificant. At the 
same time, the regression results based on the rest of sample indicate a significant and negative coefficient of DALLIANCE, as shown in Table 3.

Table 3. Sensitive Test Results

\begin{tabular}{|c|c|c|}
\hline Model & $\begin{array}{c}(1) \\
\text { Top Two Quintiles Discloser }\end{array}$ & $\begin{array}{c}\text { (2) } \\
\text { Other Disclosers }\end{array}$ \\
\hline \multirow{2}{*}{ Intercept } & 17.555 & $15.753^{* *}$ \\
\hline & $(1.11)$ & $(2.17)$ \\
\hline \multirow{2}{*}{ DALLIANCE } & -0.043 & $-0.070^{* * *}$ \\
\hline & $(-0.84)$ & $(-2.09)$ \\
\hline \multirow{2}{*}{ SIZE } & 0.087 & $0.043^{* *}$ \\
\hline & $(1.46)$ & $(2.06)$ \\
\hline \multirow{2}{*}{$A G E$} & -0.055 & -0.006 \\
\hline & $(-0.99)$ & $(-0.19)$ \\
\hline \multirow{2}{*}{$D V C$} & -0.101 & -0.010 \\
\hline & $(-0.88)$ & $(-0.27)$ \\
\hline \multirow{2}{*}{$A D J P$} & $0.878^{* * *}$ & $0.554^{* * *}$ \\
\hline & $(3.68)$ & $(4.84)$ \\
\hline \multirow{2}{*}{ PRE_RETURN } & $11.583^{* *}$ & $3.113^{*}$ \\
\hline & $(2.34)$ & $(1.8)$ \\
\hline Year and Industry Effect & Included & Included \\
\hline Cluster & Firm & Firm \\
\hline$N$ & 86 & 122 \\
\hline $\operatorname{adj.} R^{2}$ & 0.291 & 0.246 \\
\hline
\end{tabular}

$t$ statistics in parentheses and are estimated with company-clustered standard errors

${ }^{*} p<.1,{ }^{* *} p<.05,{ }^{* * *} p<.01$

IR: the closing price of the first day of IPO minus the offer price divided by the offer price; DALLIANCE: a dummy variable, one when there is an alliance before the IPO date and zero otherwise; $A G E$ : the natural logarithm of the number of years between the IPO year and the company's founding year stated in the IPO prospectus; SIZE: the natural logarithm of the original filing amount; $D V C$ : equals one when the IPO company is $\mathrm{VC}$ backed and zero otherwise. ADJP: the difference between the final offer price and the midpoint of the initial offer price range, divided by the midpoint of the initial offer price range; PRE_RETURN: the return of the CRSP equal-weighted portfolio of NYSE-, AMEX-, and NASDAQlisted stocks for the thirty trading days preceding the filing date.

In addition, since we adopt OLS analysis in our main test, the multi-collinearity is a concern. The correlation coefficients among variables in model (1), shown in Panel C, Table 1, suggest no strong correlation existed. Meanwhile, in OLS analysis, we also check Variance Inflation Factor (VIF). The VIFs are range from 1.0 to 1.5, which did not exceed 10. Therefore, according to Besley et al., 1980, we don't find the sign of multi-collinearity among variables in our current model.

\section{CONCLUSION}

This study examines whether the effect of strategic alliances on biotechnology IPO underpricing is moderated by the disclosing patterns of risk factors in IPO prospectus. Our findings suggest that though there is a significantly negative relation between strategic alliances before IPO date and underpricing, this negative association is more significant when the IPO prospectus cannot convey explicit and clear information. This study demonstrates the importance of understanding the interactions between the disclosures and the IPO company's information environment. This study contributes to the existing body of accounting research in several ways. First, this study presents the empirical evidence of the impacts of strategic alliance on the relation of risk disclosure and IPO underpricing. The results provide capital market participants important insights when they evaluate the firms' IPO offers. Particularly, it is difficult to value biotech firms due to the existence of significant information gap among manager, informed investors and uninformed investors. Second, this study helps police makers to evaluate the potential mandatary disclosure requirements on items such as pre-IPO alliance as part of filings to regulators because of its moderating effect on firm risk. In addition, this study examines the content of risk disclosure and codes the ex-ante uncertainty into scores. This method could be applied in other scenarios where the risk and uncertainty need to be measured. 
So far, we are only able to code the risk disclosure contents for biotech IPO firms. It will be interesting in the future study to also look at the risk disclosure of other industrial firms, e.g., high tech firms. By investigating firms from different industries, we might be able to generalize our conclusion on the relation between IPO underpricing and firm risk disclosure, as well the impact of strategic alliance on IPO underpricing and apply to other industrial firms.

\section{AUTHOR BIOGRAPHIES}

Ying Guo is working as an Assistant Professor of Accounting at California State University, East Bay. His research interests include earnings quality and corporate social responsibility reporting.

Tawei Wang is currently an Assistant Professor at DePaul University. He received his Ph.D. from Krannert Graduate School of Management, Purdue University in 2009. His research interests are IT management and information security management. His papers have appeared in several leading journals, including Information Systems Research, Decision Support Systems, European Journal of Information Systems, Information and Management, Information Systems Journal, Journal of Accounting and Public Policy, Journal of Banking and Finance, Journal of Information Systems, among others.

Jia-Lang Seng is currently a distinguished professor at the department of Accounting, College of Commerce, National Chengchi University in Taipei, Taiwan. Professor Seng received her Ph.D. from Robert H. Smith School of Business, University of Maryland. Her research interests center on financial reporting and financial news, information integration and information retrieval. She has published papers in Decision Support Systems, Information \&amp; Management, Information Processing \& Management, and Information Sciences. Her papers have also appeared in AAA Annual Meeting, Hawaii International Conference on System Sciences, Americas Conference on Information Systems, and Pacific Asia Conference on Information Systems.

San-Shuan Hung was a master student at National Chengchi University and currently works for PwC Taiwan.

\section{REFERENCES}

Arthurs, J. D., R. E. Hoskisson, L. W. Busenitz, and R. A. Johnson. (2008). Managerial agents watching other agents: multiple agency conflicts regarding underpricing in IPO firms. Academy of Management Journal, 51(2), 277-294.

Baron, D.P. (1982). A model of the demand for investment banking advising and distribution services for new issues. $J$ Finance, 37, 955-976

Barry, C. B., C. J. Muscarella, J.W. Peavy, and M. R. Vetsuypens. (1990). The role of venture capital in the creation of public companies. Journal of Financial Economics, 27(2), 447-471.

Beatty, R.P., and J.R. Ritter. (1986). Investment banking, reputation and the underpricing of initial public offerings. Journal of Financial Economics, 15 (1-2), 213-232.

Beatty, R. P., and E. J. Zajac. (1994). Managerial Incentives, Monitoring, and Risk Bearing: A Study of Executive Compensation, Ownership, and Board Structure in Initial Public Offerings. Administrative Science Quarterly, 39(2), 313-335.

Beatty, R.P., and I. Welch. (1996). Issuer expenses and legal liability in initial public offerings. Journal of Law and Economics, 39 (2), 545-602.

Belsley, D. A., E. Kuh, and R. E. Welsch. (1980). Regression Diagnostics: Identifying Influential Data and Sources of Collinearity. New York: John Wiley and Sons.

Benveniste, L.M., and P. A. Spindt. (1989). How Investment Bankers Determine the Offer Price and Allocation of New Issues?" Journal of Financial Economics, 24(2), 343-361.

Carter, R. B., F. H. Dark, and A. K. Singh. (1998). Underwriter Reputation, Initial Returns, and the Long-Run Performance of IPO Stocks. The Journal of Finance, 53(1), 285-311.

Cerbioni, F., and A. Parbonetti. (2007). Exploring the Effects of Corporate Governance on Intellectual Capital Disclosure: An Analysis of European Biotechnology Companies. European Accounting Review, 16(4), 791-826.

Certo, S. T., J.G. Covin, C. M. Daily, and D. R. Dalton. (2001). Wealth and the effects of founder management among IPO-stage new ventures. Strategic Management Journal, 22(6-7), 641-658.

Cyr, L. A., D. E. Johnson, and T. M. Welbourne. (2000). Human Resources in Initial Public Offering Firms: Do Venture Capitalists Make a Difference? Entrepreneurship: Theory and Practice, 25(1), 77-92.

Feltham, G.A., J. S. Hughes, and D. A. Simunic. (1991). Empirical assessment of the impact of auditor quality on the valuation of new issues. Journal of Accounting and Economics, 14(4), 375-399. 
Freedman, M. and A. J. Stagliano. (1992). European unification, accounting harmonization, and social disclosures. The International Journal of Accounting, 27(2), 112-122.

Givoly, D., and C. Shi. (2008). Accounting for Software Development Costs and the Cost of Capital: Evidence from IPO Underpricing in the Software Industry. Journal of Accounting, Auditing and Finance, 23(2), 271-303.

Gulati, R. (1999). Network location and learning: the influence of network resources and firm capabilities on alliance formation. Strategic Management Journal, 20 (5), 397-420.

Gulati, R., and M.C. Higgins. (2003). Which ties matter when? the contingent effects of interorganizational partnerships on IPO success. Strategic Management Journal, 24 (2), 127-144.

Guo, R.J., B. Lev, and N. Zhou. (2004). Competitive Costs of Disclosure by Biotech IPOs. Journal of Accounting Research, 42 (2), 319-355.

Guo, R.J., B. Lev, and N. Zhou. (2005). The Valuation of Biotech IPOs. Journal of Accounting, Auditing and Finance, 20(4), 423-459.

Hanley, K.W. (1993). The Underpricing of Initial Public Offerings and the Partial Adjustment Phenomenon. Journal of Financial Economics, 34(2), 231-250.

Hanley, K.W., and G. Hoberg. (2010). The Information Content of IPO Prospectuses. The Review of Financial Studies, 23 (7), 2821-2864.

Hughes, S. B., A. Andersonb, and S. Golden. (2001). Corporate environmental disclosures: are they useful in determining environmental performance? Journal of Accounting and Public Policy, 20(3), 217-240.

Ibbotson, R. G. (1975). Price Performance of Common Stock New Issues. Journal of Financial Economics, 2 (3), $235-272$.

Ibbotson, R. G., J. L. Sindelar, and J. R. Ritter. (1988). Initial Public Offerings. Journal of Applied Corporate Finance, 1(2), $37-$ 45.

Ibbotson, R. G., and J. R. Ritter. (1995). Initial public offerings. Handbooks in operations research and management science edited by R. A. Jarrow, V. Maksimovic, and W. T. Ziemba, North-Holland 9, 993-1016.

Jensen, M. (2004). Who gets Wall Street's attention? How alliance announcements and alliance density affect analyst coverage. Strategic Organization, 2 (3), 293-312.

Leone, A.J., S. Rock, and M. Willenborg. (2007). Disclosure of Intended Use of Proceeds and Underpricing in Initial Public Offerings. Journal of Accounting Research 45 (1), 111-153.

Ljungqvist, A., and W. J. Wilhelm. (2003). IPO Pricing in the Dot-com Bubble. The Journal of Finance, 58(2), $723-752$.

Logue, D. E. (1973). On the Pricing of Unseasoned Equity Issues: 1965-1969. Journal of Financial and Quantitative Analysis, 8 (1), 91-103.

Loughran, T., and J. Ritter. (2004). Why Has IPO Underpricing Changed over Time? Financial Management, 33(3), 5-37.

McDonald, J. and A.K. Fisher (1972), New Issue Stock Price Behaviour, Journal of Finance, 27(1), 97-102.

Megginson, W. L., and K. A. Weiss. (1991). Venture Capitalist Certification in Initial Public Offerings. The Journal of Finance, 46(3), 879-903.

Muscarella, C., and M. Vetsuypens. (1989). Initial public offerings and information asymmetry. Working paper, Southern Methodist University.

Nam, D., J.D. Arthurs, M.L. Nielsen, F. Mousa, and K. Liu. (2008). Information Disclosure and IPO Valuation: What Kinds of Information Matter and is More Information Always Better? Frontiers of Entrepreneurship Research 28.

Pisano, G.P. (1991). The governance of innovation: vertical integration and collaborative arrangements in the biotechnology industry. Research Policy, 20 (3), 237-249.

Reilly, F. K. (1973). Further Evidence on Short-run Results for New Issue Investors. Journal of Financial and Quantitative Analysis, 8 (1), 83-90.

Reilly, F. K. and and K. Hatfield (1969), Investor's Experience with New Stock Issues, Financial Analysts Journal, 25(5), 73-80

Ritter, J. R. (1984). The 'Hot Issue' Market of 1980. The Journal of Business, 57, 215-239.

Rock, K. (1986). Why new issues are underpriced. Journal of Financial Economics, 15 (1-2), 187-212.

Stoll, H. R. and A. J. Curley. (1970). Small Business and the New Issues Market for Equities. Journal of Finance and Quantitative Analysis, 5 (3), 309-322.

Stuart, T. E., H. Hoang, and R. C. Hybels. (1999). Interorganizational endorsements and the performance of entrepreneurial ventures. Administrative Science Quarterly, 44 (2), 315-349.

Weber, R. P. (1990). Basic Content Analysis. Edited by Michael S. Lewis-Beck, Quantitative Applications in the Social Sciences. Beverly Hills, Calif: Sage Publications.

Welbourne, T. M., and A. O. Andrews. (1996). Predicting the performance of initial public offerings: should human resource management be in the equation? Academy of Management Journal, 39(4), 891-919. 


\section{APPENDIX}

\begin{tabular}{|c|c|c|c|}
\hline \multicolumn{4}{|c|}{ Appendix: Risk Disclosure Four-class Index } \\
\hline Class & Score & Description & Example \\
\hline Quantitative & 4 & $\begin{array}{l}\text { If it provides quantitative } \\
\text { information. Or the risk factor is } \\
\text { clearly defined in monetary } \\
\text { terms or actual physical } \\
\text { quantities. }\end{array}$ & $\begin{array}{l}\text { Item (16) Need for additional capital: "We will need substantial } \\
\text { additional capital to fund our operations... to refinance our } \\
\$ 15.0 \text { million secured non-recourse note due to Abbott } \\
\text { Laboratories on December } 31,2007 . " *\end{array}$ \\
\hline Descriptive & 3 & $\begin{array}{l}\text { If it provides qualitative } \\
\text { information specific as to } \\
\text { actions, persons, events, or } \\
\text { places. Or the impact on the } \\
\text { company is clearly evident. }\end{array}$ & $\begin{array}{l}\text { Item (19) Dependence on key employees: “...our business plan } \\
\text { is substantially dependent on certain key members of our } \\
\text { scientific and management staff...our key personnel, including: } \\
\text { Bradford A. Zakes, our President and Chief Executive Officer; } \\
\ldots \text { and Greg Cobb, our Chief Financial Officer, would be } \\
\text { difficult to replace...”* }\end{array}$ \\
\hline Vague & 2 & $\begin{array}{l}\text { If it is mentioned only generally, } \\
\text { not specific. }\end{array}$ & $\begin{array}{l}\text { Item (13) Liability: "...We face a risk of product liability } \\
\text { exposure related to the testing of our product candidates in } \\
\text { clinical trials and will face even greater risks upon any } \\
\text { commercialization by us of our product candidates......* }\end{array}$ \\
\hline Immaterial & 1 & $\begin{array}{l}\text { Those disclosures are } \\
\text { immaterial to the financial } \\
\text { condition and results of the } \\
\text { corporation. }\end{array}$ & $\begin{array}{l}\text { Item (7) Seasonality: "... Our quarterly operating results have } \\
\text { fluctuated in the past and are likely to do so in the future...Due } \\
\text { to the possibility of fluctuations in our revenues and expenses, } \\
\text { we believe that quarter-to-quarter comparisons of our operating } \\
\text { results are not a good indication of our future performance..."** }\end{array}$ \\
\hline
\end{tabular}

* cited from S-1 Form, ImaRx Therapeutics Inc, 2007

** cited from S-1 Form, Praecis Pharmaceuticals Inc, 2000 